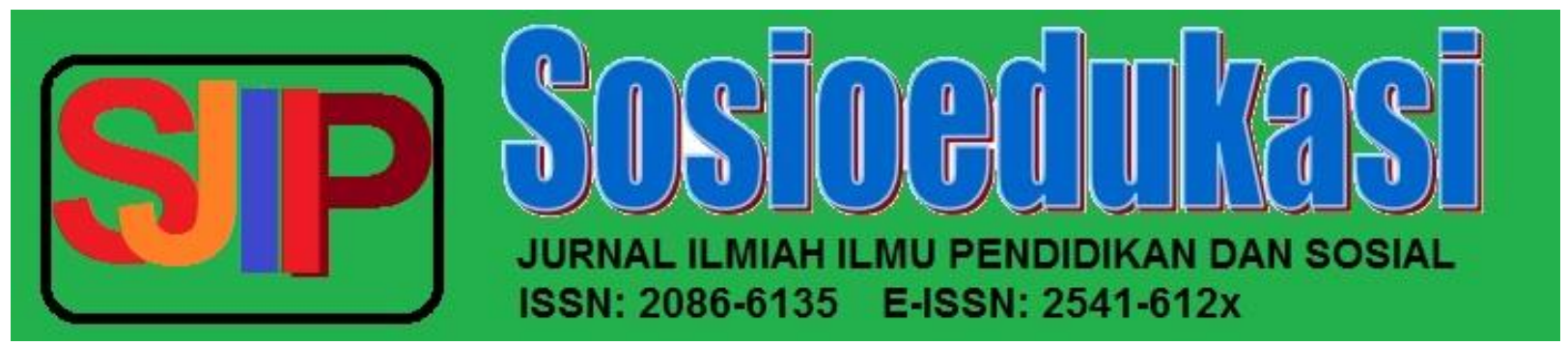

November Vol.9 No. 2 Tahun 2020 https://ejournal.unibabwi.ac.id/index.php/sosioedukasi/index

\title{
FASHION, JILBAB: BETWEEN RELIGIOSITY AND CAPITALISM, A CASE STUDY OF HIJABERS SURABAYA
}

\author{
Choirul Chamdiyatus Sholichah \\ SMAS Muhammadiyah 3 Tulangan Sidoarjo \\ diyachamdiya@gmail.com
}

\section{ARTICLE HISTORY}

Received : 2310-2020

Revised : 18-10-2020

Accepted : 17-11-2020

KEYWORDS

Fashion;

Hijab;

Religiosity;

Capitalism ;

\begin{abstract}
Hijabers Surabaya is a community of veiled women who become the mecca for young Muslim fashion. They are continuously creating the hijab with the latest fashions. Hijabs by Hijabers Surabaya are generally priced quite expensive. This situation raises the curiosity of researchers. How do Hijabers Surabaya present their lifestyle. And how is the relevance between fashion, hijab and capitalism in Hijabers Surabaya. To answer these problems, this study uses qualitative methods with the type of case study research. This qualitative research method was chosen in order to obtain in-depth and comprehensive research data regarding the lifestyle of Surabaya Hijabers and the relevance of fashion, headscarves and capitalism in Hijabers Surabaya. The data obtained were then presented descriptively and then analyzed with the social construction theory coined by Peter L. Berger.
\end{abstract}

\section{INTRODUCTIONS}

In general, humans tend to present beauty in their appearance. Anything that is worn from head to toe, is a matter that cannot be underestimated. Especially for those who live in cities, to look beautiful is not something that is difficult and impossible. There are many ways a person can still look beautiful. One of them is through the medium of fashion. Fashion can bring messages and lifestyle to a particular community which is part of social life. Fashion is part of the characteristics of modern nature which is constantly changing and developing without stopping. As explained by Soekanto, fashion means fashion that doesn't last long, which involves language style, behavior, hobbies or a preference for certain clothes (Soerjono Soekanto 2004: 186).

One form of fashion that is trending among urban Muslim women today is the hijab. Apart from being a cover for women's genitals, the hijab comes in various models, patterns, patterns and 


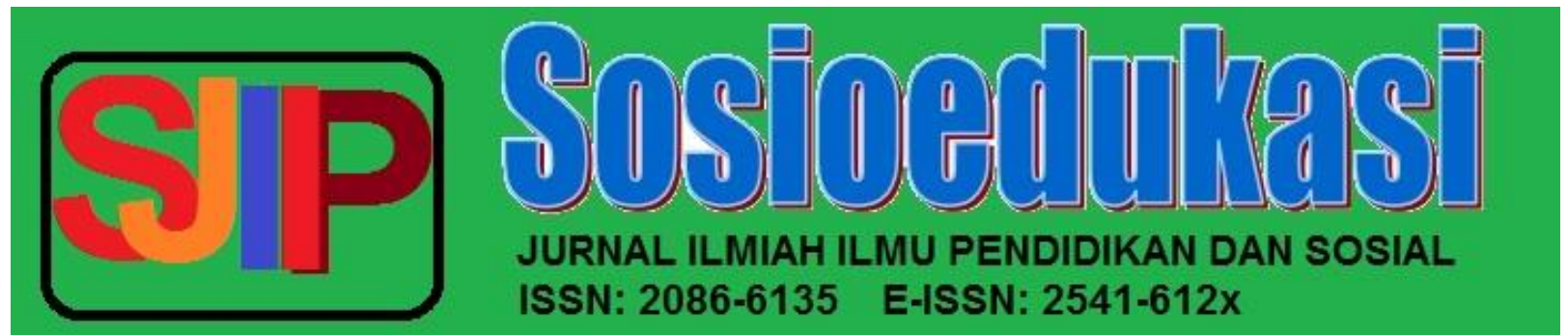

November Vol.9 No. 2 Tahun 2020

https://ejournal.unibabwi.ac.id/index.php/sosioedukasi/index

colors. Currently the hijab is one of the lifestyle icons. There are various models that can be chosen by women freely to express themselves. The widespread use of the hijab and clothing as a fashion among women is also inseparable from the role of designers hijab. One of them is Dian Pelangi, a Muslim fashion designer who later founded the Hijabers Community. Hijabers Community is a group of beautiful Muslim women who wear the hijab (hijab) in urban, stylish and fashionable styles. (Vivaonline.com 2011).

The appearance of Hijabers Surabaya brings the spirit of religious life. The veil has become symbols or artifacts that show the piety of the wearer, however, this religious spirit at the level of religious symbols has become the target of the capitalism cultural industry. The widespread use of religious symbols that are not accompanied by a level of awareness and understanding can make religious practice and experience nothing more than mere commodities. Hijabers Surabaya seems to continue to introduce trendy hijab styles, especially through the moeslem fashion show.

Hijabers Surabaya members, almost all of them have a headscarf and clothes that are becoming a fashion trend. In every meeting, this Surabaya Hijabers member always wears a dress code that matches the specified theme. They want to build an image as a stylish, fashionable and beautiful Muslim woman through the hijab. So that the number of enthusiasts of hijab and clothing with Hijabers style is increasing. The religious symbol then seems to be a business that can bring huge profits among Hijabers.

The increasing number of women wearing the headscarf is also inseparable from the role of the media which continues to highlight the journey of Hijabers Surabaya, such as television and social networks. Hijabers Surabaya utilizes social networking media, such as Facebook, Twitter and Instagram to promote various events being held, such as holding grand recitations at mosques, holding Hijab classes, member gatherings, bazaars or Muslim fashion markets at malls and other places at no cost. cheap.

On the other hand, the fashion developments that are heavily campaigned by Hijabers Surabaya can indicate a new need in the lives of Muslim women, namely the need for a hijab that shows the social status of the wearer. In the end, Muslim women consume the hijab according to a growing fashion to be stylish. Muslim women are now more daring to appear and even show luxury through the hijab they wear. Some of them switched their fashion from conventional hijab to hijab style hijabers. 


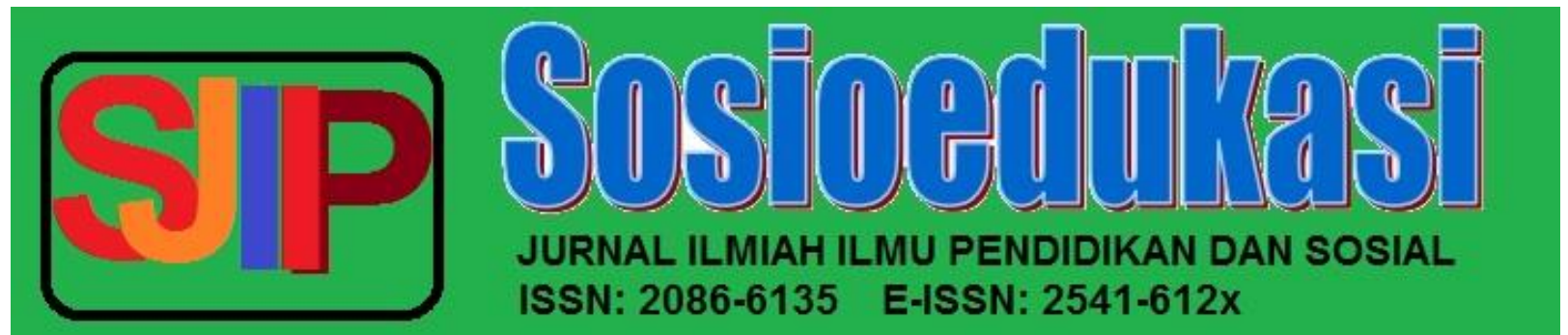

November Vol.9 No. 2 Tahun 2020 https://ejournal.unibabwi.ac.id/index.php/sosioedukasi/index

Hijabers' style hijab not only moves the hearts of those who are already veiled to appear bolder, but also the hearts of Muslim women who are not yet veiled to carry out their obligation to cover their genitals. Religious awareness among Muslim women seems to be mixed with trying to follow fashion. On the other hand, Hijabers Surabaya, which is the center of fashion for young Muslim women, continues to create hijabs with the latest fashions. Hijabs made by Hijabers Surabaya are generally priced quite expensive. This situation raises the researchers' curiosity about how this group of Hijabers presents their lifestyle. How is the relevance between capitalism and the increasing religious awareness of this veiled community?

\section{MATERIALS AND METHODS RESEARCH LOCATION}

This paper is written based on research using qualitative methods with the type of case study research that focuses more on social construction. the author conducted in-depth interviews and observations of the Surabaya hijabers community. This research subject search technique, using purposive sampling technique, (sampling technique is based on certain objectives). Because the samples were taken according to certain criteria to get a thorough understanding of the problems in this study. The criteria for informants in this study were based on: involvement since the inception of Hijabers Surabaya until their development, position in the management structure, occupation and marital status. Based on these criteria the writer selects and then determines the research subjects. The author interviewed eight informants. Five of them are those who are in the management of Hijabers Surabaya. Meanwhile, the other three informants are active members. In addition, the results of observations in the form of photos or images are also used as material for analysis to explain more concretely the variations in the identity of Jilbab users in the Hijabers Surabaya community.

\section{RESULTS AND DISCUSSIONS}

To analyze what the Muslim women in hijab who joined Hijabers Suarabaya did, the researcher used the Social Construction theory of reality that was put forward by Peter L. Berger as a tool of analysis. According to Berger, society is a dialectical phenomenon in the sense that society is a human product, which will always give reciprocity to the producer. Berger views society as a process that takes place in three simultaneous dialectical moments, namely externalization, 


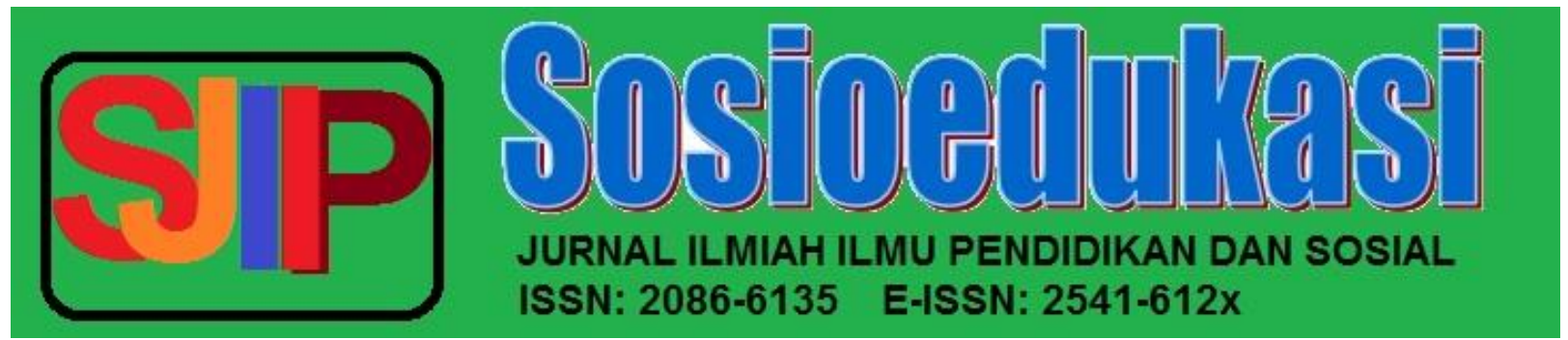

November Vol.9 No. 2 Tahun 2020 https://ejournal.unibabwi.ac.id/index.php/sosioedukasi/index

objectivation and internalization. This is what is called social reality (Bagong Suyanto and Khusna Amal, 2016: 143).

Externalization is the outpouring of human selfhood continuously into the world, both in physical and mental activities. Objectivation is the bearing of the products of that activity (both physical and mental), a relation that is faced with the original producers, in the form of a facticity which is external to and other than the producers themselves. Internalization is the re-permeation of this reality by humans, and transforming once again from the structures of the objective world into

the structures of subjective consciousness. Through externalization, society is a human product. Through objectivation, society becomes a unique sui generis reality.

Through internalization, humans are a product of society. Human existence is primarily and ultimately an externalizing activity. During the process of externalization, humans pour meaning into reality. Every human society is an externalized and objectivated meaning building, always leading to a meaningful totality. Religion has played a strategic role in human efforts to build the world. Religion is the farthest reach from the externalization of the human self, from the absorption of its own meaning into reality. Socialization is said to be successful if the situation is successfully internalized.

The internalization process must always be understood as one of the momentum of a larger dialectical process which also includes the externalization and objectivation momentum. If this is not done, a picture of mechanistic determinism will emerge, in which the individual is produced by society as the cause that produces nature. Internalization is not only part of the dialectic of larger social phenomena, but individual socialization also occurs in a dialectical way. As happened in Hijabers Surabaya. As a gathering place for Muslim women with headscarves, which was established by a Muslim woman with a background of models, writers and fashion observers, it will contribute to constructing the way of life of her followers, through the way of veiling, how to consume goods to complement their appearance, how to consume space, and how to choose reading themed on fashion, as well as how to choose make-up, etc.

The construction here goes through three dialectical processes, namely internalization, externalization and objectivation. Internalization is the re-permeation of this reality by humans, and transforming once again from the structures of the objective world into the structures of subjective consciousness. Internalization is a mechanism for instilling values and changing people's behavior. Value planting will be successful if people are willing to leave something old and replace it with a 


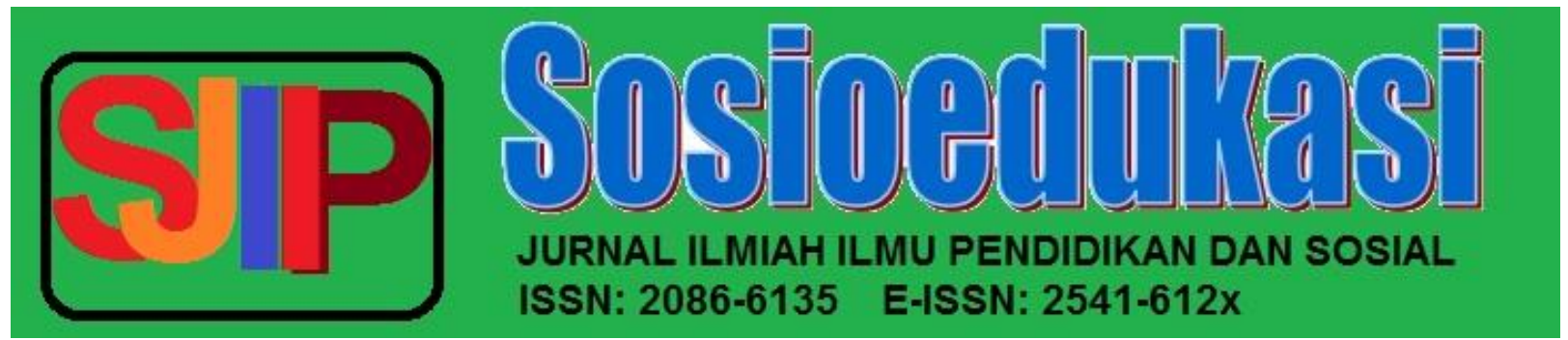

November Vol.9 No. 2 Tahun 2020 https://ejournal.unibabwi.ac.id/index.php/sosioedukasi/index

new one. Meanwhile, externalization refers to the human creative process. through externalization man expresses himself by constructing his world.

Through this externalization, society becomes a man-made reality. Reality becomes objective reality, a reality separate from humans and dealing with humans. Society with its social institutions will influence and even shape human behavior. from this point of view it can be said that society is reabsorbed by humans through a process of internalization. The following is a dialectical process chart to understand the concept of internalization, externalization, objectivation that occurs in Hijabers Surabaya. The

first thing that the researcher will discuss is the internalization that occurs in Hijabers Surabaya. Talking about internalization, it cannot be separated from the discussion about delivery and acceptance. The delivery actor here is the founder. We can make the founder of Hijabers Surabaya as an agent of socialization. Because it is the founder who conveys the values and norms in the community. The founder then reproduces the values and norms to the Surabaya Hijabers leader. The leaders in Hijabers Surabaya also determine and spread the values and norms to stabilize the Hijabers Surabaya members.

The leader of Hijabers Surabaya, has an important role because directly or indirectly, the followers of this community, internalize whatever the Surabaya Hijabers leaders say or teach. They believe that whatever the leader says is their version of the correct teaching. Like the hijab and fashion modification, it will give a beautiful, fashionable look and will not leave Islamic law. Therefore, they want to practice what the founder of Hijabers Surabaya said. Although sociologically, the things conveyed by the Surabaya Hijabers leader are the result or product of the founder's thoughts and reproduced in the leader. In addition, the Hijabers Surabaya members know the background of the Surabaya Hijabers leader who incidentally comes from the world of models and designers. I don't know from a personal account on the social media of the Hijabers Surabaya leader.

The leader of Hijabers Surabaya often uploads various styles of fashionable, fashionable, hijab in their personal accounts such as Instagram or Facebook, Path and Twitter. So that women in Hijabers Surabaya are seen as beautiful and fashionable women. The belief of Muslim women who are members of Hijabers Surabaya, in what is conveyed by the leaders of Hijabers Surabaya is accompanied by the knowledge they get from social media. So that Muslim women will believe 


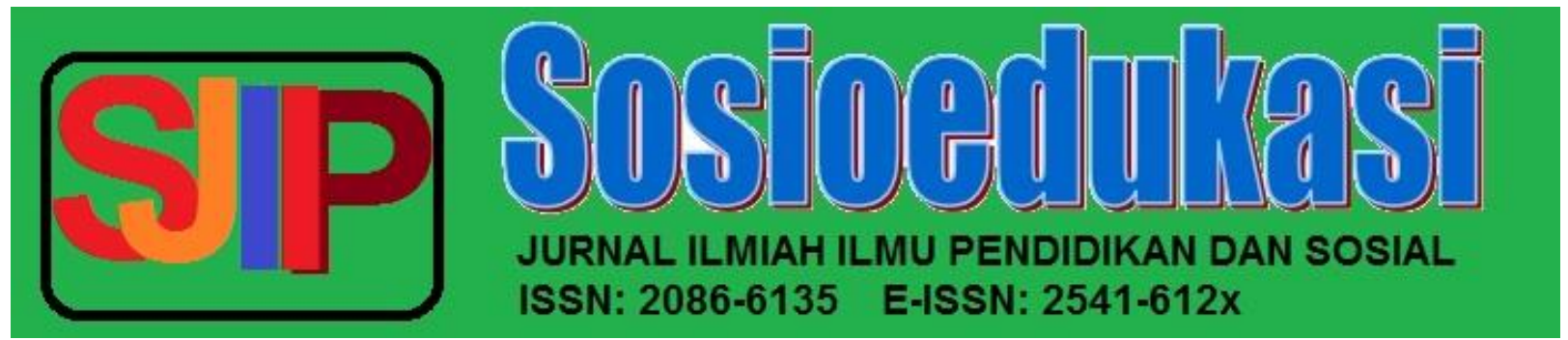

November Vol.9 No. 2 Tahun 2020 https://ejournal.unibabwi.ac.id/index.php/sosioedukasi/index

that the beautiful construction of Hijabers is what is seen from the various personal accounts of other Hijabers Surabaya leaders and management.

Apart from discussing the delivery process, internalization also discusses the acceptance process. In this case, how is the process of accepting hijab modification with fashion so as to give a fashionable look to Hijabers Surabaya. In the internalization process related to meaning, each informant has a different meaning. This is based on the internalization process that has been obtained.

In fact, what is used by the leader of Hijabers Surabaya, Muslim women will also use it. Because it is considered to be able to give an attractive appearance to the wearer as has been implemented by Hijabers Surabaya members. Apart from displaying their religious lifestyle by wearing headscarves, they also consume make-up. At first, they didn't dare to use make-up because they didn't have a halal label. After knowing that Muslim women in Hijabers Surabaya use makeup Wardahwith the halal label. So they use Wardah make-up because there is an Islamic sign, which is halal.

Wardah is a cosmetics labeled halal for Muslim women. Hijabers Surabaya prefer to use make-up labeled halal because the ingredients have also been clinically tested. Not only that, the way they (Hijabers Surabaya members) look for entertainment is also inseparable from the internalization process of participating in several Hijabers Surabaya activities and seeing some of Hijabers Surabaya's personal accounts. Where Hijabers Surabaya always hold various activities in places that are constructed as hangout places for slang kids, such as malls, cafes, restaurants. So Muslim women in Hijabers Surabaya consume space like other members. Apart from entertainment, they also externalize the determination of dress code by Hijabers Surabaya. Determination of the dresscode with various rules such as not being strict, leggings, jeans will be applied in a dress style. If the clothes they own are no longer in accordance with the theme and rules that have been set, they will buy. Because they don't want to be alienated or alienated by their environment.

In the process of searching for ideas or externalizing values to provide solutions to conditions that exist in society.modification Fashion with the hijab by Hijabers Surabaya as a transformation mechanism by creating new ideas in the hijab style of Muslim women. Hijabers Surabaya wants to invite Muslim women to look beautiful, fashionable with a 


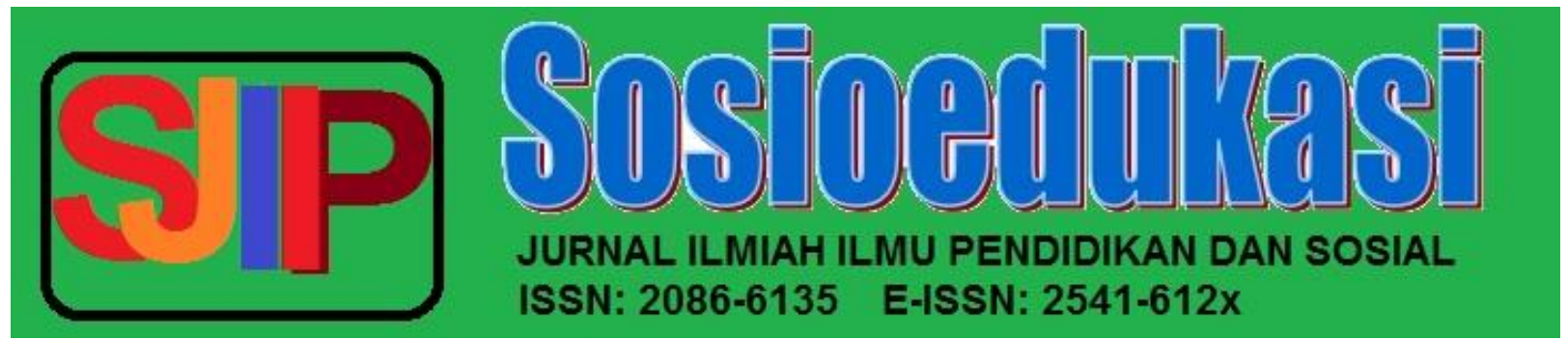

November Vol.9 No. 2 Tahun 2020 https://ejournal.unibabwi.ac.id/index.php/sosioedukasi/index

headscarf without leaving Islamic law. Hijabers Surabaya use fashion in hijab as a broadcast medium. Furthermore, the idea was objectified by Surabaya Hijabers members as an objective reality. After we discuss internalization and externalization, now we discuss the objectivations that exist in Hijabers Surabaya.

Objectivation itself means the bearing of the products of that activity (both physical and mental), a relation which is faced with the original producers, in the form of a fact (facticity) which is external to and other than the producers themselves. Something can be said as objectivation if it becomes a culture in a particular society. Culture is meant here is a pattern for action, which becomes a reference for human actions or thoughts. The pattern for action referred to in this research is that what is taught by the leaders and management of Hijabers Surabaya is very influential for the actions taken by Hijabers Surabaya members. Until almost all the Hijabers Surabaya members follow what is taught by the Surabaya Hijabers leader as stated in the internalization and externalization process.

The results of their internalization and externalization produce a product or object that characterizes them. Based on the above discussion, we can conclude that Muslim women in Hijabers Surabaya have characteristics in presenting their lifestyle. For example, in terms of appearance, they use a fashionable hijab (adapted to fashion) and their respective characteristics. As well as wearing a long dress or maxi in Islamic activities. They modify the fashion and the hijab and make it a go-to tool.

In terms of religious activities, Muslim women in Hijabers Surabaya hold various religious activities such as recitation and charity as well as fashion-themed activities in classy places. In terms of make-up, they use make-up with a halal label like wardah. With their objectivation like that, both in appearance and in thought. This gives the impression that Hijabers are attached to a consumptive, exclusive, commercial identity. They want to show their religiosity as well as modernity through their lifestyle. Such as wearing a fashionable headscarf, consuming prestigious places, consumption complementary appearance (hijab and fashion), consumption of Islamic magazines and fashion, consumption of cosmetics.

Muslim women in Hijabers Surabaya wear a fashionable headscarf (adjusted to the development of fashion), therefore the veil has developed a meaning. The hijab, which is believed to be a religious symbol that has religious values, is now a symbol of modernity. The meaning of modernity can be seen from the inclusion of fashion elements in the hijab which have up to date 


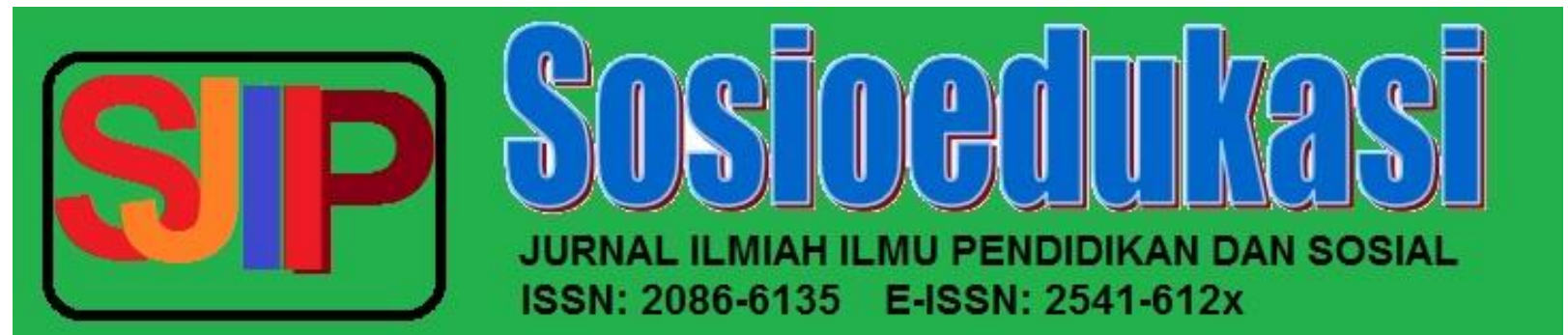

November Vol.9 No. 2 Tahun 2020 https://ejournal.unibabwi.ac.id/index.php/sosioedukasi/index

principles. Meanwhile, the presence of fashion and headscarves is hybridized because the elements of fashion which have become popular culture meet the hijab as a clothing covering the genitals which has become a local Islamic culture.

The element of fashion that offers freedom of expression, the typical consumption of capitalism is in contrast to the veil which is also a symbol of simplicity or zuhudan. The fashionable hijab in Hijabers is also interpreted as a means of sharing to invite Muslim women to wear the hijab. This is because they also have a special agenda that carries their interests, namely, boosting the sales of the hijab and helping to advance the economy of community members who have a fashion label. Like the hijab construction that was built by the Surabaya Hijabers leader. He gave a new discourse on the hijab.

In the past, the veil received a meaning as an ancient, outdated and conservative (stiff) women's dress. Some Muslim women are not interested in using it. After the emergence of a contemporary hijab community such as Hijabers Surabaya, the hijab received a new meaning from its founder. The veil is constructed as a clothing covering the genitals that can be created and combined with fashion. Fashion modification with hijab can make Muslim women look more beautiful and fashionable. But still guided by Islamic law in dress. The entry of fashion in the hijab is used as a means of sharing to invite Muslim women to wear the hijab. The myth of beauty with the fashionable hijab in the style of Surabaya Hijabers is a supporting factor in influencing the perceptions of its members.

It can be said that the dialectical process of the Surabaya Hijabers members begins with objectivation. They have seen the pre-existing reality about the criteria for beauty in hijab style Hijabers Surabaya. They started wearing cosmetics and fashionable headscarves to identify themselves with other members. With the standardization of beauty in hijab that is determined by the founder of Hijabers Surabaya. This will affect the thinking of its members that beauty in

veiling is important as a way to be grateful for Allah's blessings. Beauty in veiling is also interpreted by its members as a form of self-care.

\section{CONCLUSION}

Fashion and headscarves in Hijabers experience a hybridization because the elements of fashion that have become popular culture meet with the hijab as a clothing covering the aurat which is the local Islamic culture. The element of fashion that offers freedom of expression, the typical 


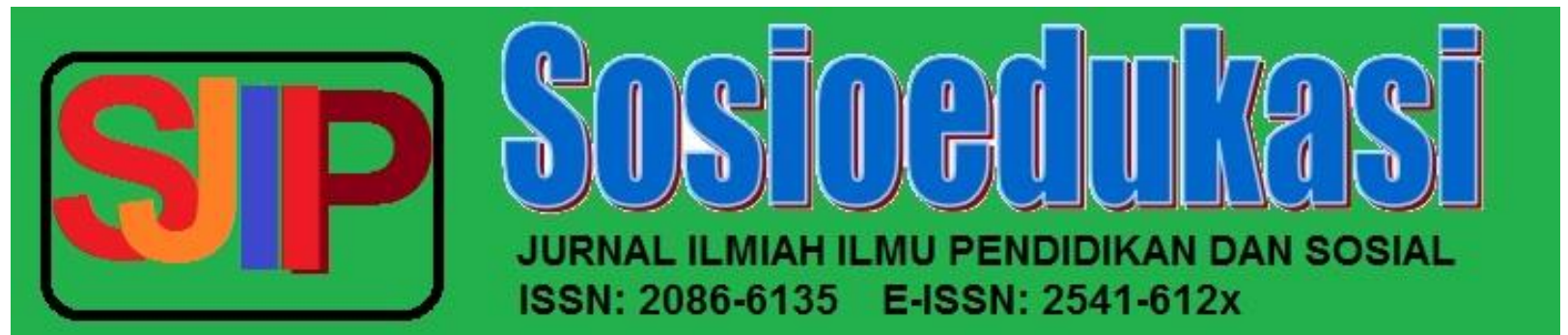

November Vol.9 No. 2 Tahun 2020 https://ejournal.unibabwi.ac.id/index.php/sosioedukasi/index

consumption of capitalism is in contrast to the veil which is also a symbol of simplicity or zuhudan. Thehijab fashionable in Hijabers is also interpreted as a means of sharing to invite Muslim women to wear the hijab. Because they also have a special agenda that carries their interests, namely, boosting hijab sales by popularizing various hijab models to advance the economy of community members who have alabel fashion.

\section{REFERENCES}

Adlin, Alfathri. 2006. Resistensi Gaya Hidup Teori dan Realitas, Yogyakarta: Jalasutra, 2006. Adlin, Alfatri, Menggeledah Hasrat: Sebuah Pendekatan Multi Perspektif, Yogyakarta: Jalasutra,

Berger, Peter L. 1990. Tafsir Sosial Atas Kenyataan, Pengantar oleh Frans M. Parera, Jakarta: LP3ES,

Chaney, David, 2006. Life Style Sebuah Pengantar Komprehensif, Cet-II, (Yogyakarta: Jalasutra, El-Guindi, Fadwa, 2006. Jilbab Antara Kesalehan, Kesopanan dan Perlawanan, Jakarta: Serambi.

Fitri, Idatul dan Khasanah, Nurul, 2011. 60 Kesalahan Dalam Berjilbab, Cet-1, Jakarta: Basmalah.

Shihab, Quraish, 2004. Jilbab Pakaian Wanita Muslimah, Jakarta: Lentera Hati,.

Soedjatmiko, Haryanto Saya Berbelanja, maka Saya Ada Ketika Konsumsi dan Desain Menjadi Gaya Hidup Konsumeris, Yogyakarta: Jalasutra, 2008.

Piepiet Tri Noor Astuti \& Lutfi Dwi Puji Astuti, 2007. Berjilbab Bukan Berarti Kampungan, VIVA (online), (2 Agustus 2011, 11.13 WIB) dalam (http://www.analisis.news.viva.co.id/new/read/ 237510-berjilbab-bukan-berarti-kampungan, diakses 4 April 2014). Republika, Rubrik Mode, dalam Ainurrofiq Dawam, - Jilbab Dalam Perspektif Sosial Budayall, Innovatio (online), Vol.6, No. 12. Edisi Juli-Desember,(https://www.lib.atmajaya.ac.id/ default.aspx?tabID=61\&src=k\&id=1 78023, diakses 13 Maret 2014), hal. 366. 